\title{
A SUBSTITUIÇÃO DOS EMBARGOS INFRINGENTES PELAS TÉCNICAS DE JULGAMENTO COLEGIADO NO TRIBUNAL DE JUSTIÇA DO CEARÁ: EFEITOS SOBRE A CELERIDADE PROCESSUAL ${ }^{1}$
}

THE REPLACEMENT OF “EMBARGOS INFRINGENTES” BY COLLEGIAL JUDGMENT IN THE COURT OF JUSTICE OF CEARÁ: EFFECTS ON PROCESS SPEEDINESS

Lethicia Pinheiro Machado Pesquisadora do Projeto Pesquisa Empírica em Direito (Cnpq) vinculado ao curso de Direito da Universidade de Fortaleza - UNIFOR. Especialista em Direito e Processo Penal pelo Centro Universitário Sete de Setembro - Uni7. Advogada.

Fortaleza/CE. E-mail: lethiciapinheiromachado@ hotmail.com

José Victor Ibiapina Cunha Morais Especialista em Direito e Processo Penal pelo Centro Universitário Sete de Setembro - Uni7. Graduado em Direito pela Universidade de Fortaleza - UNIFOR. Pesquisador do Projeto Pesquisa Empírica em Direito (Cnpq) vinculado ao curso de Direito da Universidade de Fortaleza - UNIFOR. Coordenador da $1^{\text {a }}$ Câmara Criminal do TJ/CE. Fortaleza/CE. E-mail: victoribiapinacunha@hotmail.com>

Eduardo Régis Girão de Castro Pinto Doutorando em Direito Constitucional e Mestre em Direito Constitucional pela Universidade de Fortaleza. Professor do Curso de Pós-Graduação lato sensu em Processo Civil da Escola Superior da Magistratura do Estado do Ceará.

\footnotetext{
${ }^{1}$ Artigo recebido em 14/05/2019 e aprovado em 27/08/2019.
} 


\section{Professor dos Cursos de Pós-Graduação lato sensu em Direito Empresarial, Direito dos Contratos e Responsabilidade Civil e Direito do Consumidor, e do Curso de Graduação em Direito na UNIFOR. Pesquisador do Projeto Pesquisa Empírica em Direito (Cnpq/UNIFOR). Assessor jurídico da Corregedoria Geral da Justiça do Estado do Ceará. Fortaleza/CE. E-mail: eduardorg@unifor.br}

Mariana Dionísio de Andrade Doutora em Ciência Política pela Universidade Federal de Pernambuco. Mestre em Direito Constitucional pela Universidade de Fortaleza - UNIFOR. Especialista em Direito Processual Civil pela UNIFOR. Professora do Curso de Pós-Graduação lato sensu em Direito e Processo Constitucionais e da disciplina Teoria Geral do Processo Civil no Curso de Graduação em Direito na Universidade de Fortaleza. Formação em Leadership and Conflict Management pela Stanford University. Formação em Métodos Quantitativos pela UERJ. Pesquisadora do Grupo Epistemologia e Método na Ciência Política Comparada (Cnpq/UFPE). Coordenadora do Projeto Pesquisa Empírica em Direito (Cnpq/ UNIFOR). Pesquisadora do Laboratório de Ciências Criminais - LACRIM (Cnpq/UNI- FOR). Advogada. Fortaleza/CE. E-mail: mariana.dionisio@unifor.br

RESUMO: O estudo responde ao seguinte problema de pesquisa: qual a influência que a substituição dos embargos infringentes pelas técnicas de julgamento exerce sobre a celeridade processual? Desenvolve-se pesquisa quantitativa e qualitativa, com abordagem exploratória e bibliográfica. Com base em pesquisa de campo no Tribunal de Justiça do Ceará e análise comparativa entre os embargos infringentes processados desde 2014 até março de 2019 e as técnicas de julgamento realizadas até a referida data. Conclui-se que a 
técnica de julgamento prestigiou a celeridade processual, pois o tempo que o instituto adiciona ao trâmite processual é inferior ao lapso necessário ao recurso.

PALAVRAS-CHAVE: Celeridade Processual; Razoável Duração do Processo; Embargos Infringentes; Técnica de Julgamento; Tribunal de Justiça do Ceará.

ABSTRACT: The study responds the following research problem: what influence the substitution of the "embargos infringentes" by the judgment technique exerts on the speed of process? Quantitative and qualitative research is developed, with an exploratory and bibliographic approach. Based on field research in the Court of Justice of Ceará and comparative analysis between the "embargos infringentes" processed from 2014 until March 2019, and the judgment technique carried out until that date. Conclude that the trial technique improved the procedural speed, since the time that the institute adds to the procedural process is less than the lapse necessary to the appeal.

KEY WORDS: Process Speediness; Reasonable duration of the Process; Appeal; Judgment Technique; Court of Justice of Ceará.

\section{INTRODUÇÃO}

Uma das medidas adotadas pelo Código de Processo Civil de 2015 para efetivar a celeridade processual foi a supressão do recurso de embargos infringentes e inclusão da técnica de julgamento em seu artigo 942. Em síntese, o recurso tinha o objetivo de solucionar divergências em julgamento de apelação e ação rescisória em órgãos colegiados. A técnica de julgamento, por sua vez, é aplicada durante o julgamento dos recursos de apelação e agravo de instrumento, bem como ação rescisória, como o mesmo objetivo de sanar eventuais julgamentos com divergência em colegiados.

Assim, o trabalho busca responder ao seguinte problema de pesquisa: qual a influência que a substituição dos embargos infringentes pelas técnicas de julgamento exerce sobre a celeridade processual? O estudo demanda pesquisa de campo em Tribunal de Justiça para acessar os dados necessários à solução do questionamento ora proposto. 
O recorte espacial para a presente pesquisa se concentra no Tribunal de Justiça do Ceará, o que se justifica pela disponibilidade dos dados, que permitirá uma análise do contexto de forma mais aprofundada, vinculando o assunto à realidade local de um dos tribunais com o maior número de demandas do Nordeste brasileiro, e principalmente, por se tratar do Tribunal estadual menos produtivo, conforme informações do Relatório Justiça em Números 2018 do Conselho Nacional de Justiça.

Tem-se como objetivo geral analisar quais os efeitos causados pela substituição dos embargos infringentes pela técnica de julgamento à celeridade processual. Como objetivos específicos, visa-se compreender os princípios da razoável duração do processo e da celeridade processual, bem como o recurso de embargos infringentes e a técnica de julgamento. Objetiva-se também comparar a quantidade de embargos infringentes opostos anteriormente ao CPC/15 com o número de aplicações de técnicas de julgamento após a vigência do Código no Tribunal de Justiça do Ceará, e verificar o tempo de tramitação em segundo grau para os casos de acórdãos não unânimes e comparar com o período após a vigência do $\mathrm{CPC} / 15$, no mesmo tribunal.

Passa-se então ao estudo dos princípios da razoável duração do processo e da celeridade processual, no primeiro tópico. No segundo, serão abordados os embargos infringentes e a técnica de julgamento, assim como as bases doutrinárias que fundamentam os posicionamentos a favor e contra a supressão daquela modalidade recursal, e, a partir da comparação da quantidade de embargos infringentes interpostos com o número de aplicações de técnica de julgamento, verificar possíveis consequências da substituição do recurso pela técnica de julgamento.

Por fim, no terceiro tópico, será realizado levantamento do tempo de tramitação de julgados com divergência antes e depois da vigência do CPC/15, a fim de verificar se houve promoção da celeridade e, consequentemente, efetividade da proposta de alteração legislativa na redução de modalidades recursais.

No que toca à metodologia do presente trabalho, desenvolveu-se pesquisa predominantemente qualitativa e com elementos quantitativos, primando-se por uma abordagem exploratória, comparativa e bibliográfica na medida em que se utilizou como fonte de pesquisa livros, artigos científicos e periódicos sobre o tema. Desenvolveram-se nos dois primeiros tópicos, como dito, os conceitos relevantes para a devida compreensão 
Rio de Janeiro. Ano 13. Volume 20. Número 3. Setembro a Dezembro de 2019

Periódico Quadrimestral da Pós-Graduação Stricto Sensu em Direito Processual da UERJ

Patrono: José Carlos Barbosa Moreira (in mem.). ISSN 1982-7636. pp. 239-267

www.redp.uerj.br

do tema, de modo que, no terceiro tópico fora desenvolvida pesquisa eminentemente quantitativa.

Para a obtenção das informações concernentes às técnicas de julgamento fora realizada pesquisa de campo nas secretarias das quatro Câmaras de Direito Privado do Tribunal de Justiça do Ceará, para a obtenção de certidões emitidas pelos respectivos coordenadores. A $2^{\mathrm{a}}$ e a $4^{\mathrm{a}}$ Câmaras de Direito Privado forneceram certidões nas quais constavam em anexo os ofícios expedidos para atender ao disposto no art. 942 do CPC, ao passo que a $1^{\mathrm{a}}$ e a $3^{\mathrm{a}}$ Câmaras de Direito Privado, anexaram às certidões relações contendo os números dos processos nos quais foram utilizados tal instituto. O corte temporal solicitado teve por termo inicial a vigência do novo CPC (março de 2016) e termo final o mês final de coleta de dados para a pesquisa, 13 de março de 2019, solicitação que foi atendida por todas as Câmaras de Direito Privado, com exceção de $3^{\text {a }}$, cujos dados tiveram por termo inicial o ano de 2017, data na qual o atual coordenador da secretaria assumiu e iniciou o arquivamento dos dados solicitados.

Já no tocante aos dados referentes aos embargos infringentes, fora realizado um requerimento veiculado por meio do processo administrativo de $n^{\circ}$ 850439193.2019.8.06.0000 que tramitou perante o Tribunal de Justiça do Ceará sendo fornecido pela Secretaria de Tecnologia e Informação a relação com números dos referidos recursos interpostos e julgados desde o ano de 2014 até a data da solicitação, 13 de março de 2019.

Por fim, após a análise e comparativo dos dados obtidos, é possível analisar a questão da morosidade processual como uma grande moléstia que acomete o Judiciário brasileiro, a qual não afeta somente as partes envolvidas na lide processual, mas o desenvolvimento da sociedade brasileira. Nessa conotação, a relevância social e jurídica do tema decorre, portanto, da necessidade de verificar se o Código de Processo Civil de 2015 realmente alcançou seu objetivo de efetivar a celeridade processual ao substituir os embargos infringentes pela técnica de julgamento. A relevância teórica repousa na contribuição inédita sobre o tema, a partir de uma análise comparativa baseada em padrões numericamente mensuráveis.

\section{CELERIDADE PROCESSUAL E RAZOÁVEL DURAÇÃO DO PROCESSO}


Rio de Janeiro. Ano 13. Volume 20. Número 3. Setembro a Dezembro de 2019

Periódico Quadrimestral da Pós-Graduação Stricto Sensu em Direito Processual da UERJ

Patrono: José Carlos Barbosa Moreira (in mem.). ISSN 1982-7636. pp. 239-267

www.redp.uerj.br

No contexto internacional, a luta pela celeridade processual teve sua origem no mesmo período que as reivindicações por direitos e garantias fundamentais. ${ }^{2}$ Como uma reação às atrocidades vistas pelo mundo na segunda guerra mundial, a busca pela positivação de garantias processuais alcançou uma dimensão universal sendo adotada, como exemplo, por países que se libertaram de ditaduras como Alemanha, Itália e Japão. ${ }^{3}$

No Brasil, o vínculo entre Constituição e processo se fortificou com a Constituição de 1988, pois esta tratou de importantes pontos do direito processual, prevendo, em favor do jurisdicionado, direitos fundamentais vinculados ao processo. Elaine Harzheim Macedo e Shana Serrão Fensterseifer ${ }^{4}$ chamam tais direitos de garantias constitucional-processuais.

A garantia da celeridade processual, todavia, somente foi positivada na Constituição Federal com a Emenda Constitucional $n^{\circ} 45$ de 2004, que incluiu no rol de garantias fundamentais a razoável duração do processo e a celeridade na tramitação (artigo $5^{\circ}$, LXXVIII, da Constituição Federal). Tal previsão ocorreu de forma tardia se comparada ao contexto jurídico mundial, uma vez que no ano de 1969 foi publicado o Pacto de San José da Costa Rica reconhecendo tais garantias, acordo assinado pelo Brasil em $1992 .^{5}$

A alteração constitucional de 2004 não criou novo instituto no direito brasileiro, mas teve importante função de posicioná-lo no centro do ordenamento jurídico, os princípios foram incluídos no rol de cláusulas pétreas como normas de direitos fundamentais. ${ }^{6}$ Essas normas são autoaplicáveis, dispensando atuação do Poder Legislativo para ter eficácia, por imposição do artigo $5^{\circ}, \S^{\circ}$ da Constituição Federal de 1988.

Apesar da positivação da razoável duração do processo e da celeridade processual na Constituição datar de 2004, sua previsão constitucional já deveria ser reconhecida pelo artigo $5^{\circ}$, LIV, e $\S 2^{\circ}$ da CF, bem como artigo $8^{\circ}$, n. 1 da Convenção Americana sobre Direitos Humanos. Contudo, até a Emenda Constitucional no 45, o Supremo Tribunal Federal, adotando posicionamento contrário à doutrina majoritária, entendia que as normas advindas de tratados internacionais ingressavam no ordenamento jurídico brasileiro como

\footnotetext{
${ }^{2}$ MACEDO, Elaine Harzheim; CARVALHO, Volgane Oliveira. A duração razoável do processo no direito brasileiro e o novo código de processo civil: avanços e recuos. Revista Eletrônica de Direito Processual REDP, v. 15, n. 15, 2015, p. 74-106.

${ }^{3}$ MACEDO, Elaine Harzheim; FENSTERSEIFER, Shana Serrão. O direito fundamental à tutela jurisdicional tempestiva na perspectiva constitucional e o caso problemático da sentença sem eficácia imediata ope legis que tutela direito em risco de dano ou perecimento. Revista de Processo, v. 237/2014, nov/2014, p. 13-41

${ }^{4}$ Ibid.

5 PRIEBE, Victor Saldanha; SPENGLER, Fabiana Marion. A razoável duração do processo na jurisdição brasileira. Revista Eletrônica de Direito Processual - REDP, v. 18, n. 2, 2017, p. 165-191.

${ }^{6}$ MACEDO, Elaine Harzheim; CARVALHO, Volgane Oliveira, op. cit.
} 
Revista Eletrônica de Direito Processual - REDP.

Rio de Janeiro. Ano 13. Volume 20. Número 3. Setembro a Dezembro de 2019

Periódico Quadrimestral da Pós-Graduação Stricto Sensu em Direito Processual da UERJ

Patrono: José Carlos Barbosa Moreira (in mem.). ISSN 1982-7636. pp. 239-267

www.redp.uerj.br

lei infraconstitucional. A celeridade e razoável duração do processo, portanto, somente adquiriram status constitucional em $2004 .^{7}$

O inciso LXXVIII do artigo $5^{\circ}$ da Constituição Federal de 1988, trata de dois princípios constitucionais diversos, os quais abordam direitos fundamentais independentes, com conceitos e objetivos distintos, ambos integrantes do processo democrático de direito constitucionalmente previsto. Assim, embora o processo seja célere em algumas fases de sua tramitação, é possível que não tenha tido duração razoável, e vice-versa. ${ }^{8}$

Inicialmente, analisar-se-á a garantia da razoável duração do processo, conceituada por Elaine Harzheim Macedo e Volgane Oliveira Carvalho ${ }^{9}$ como a busca por regras processuais que tenham a função de inibir práticas que configurem abuso de direito pelo Estado ou pelas partes litigantes, como forma de garantir segurança jurídica e a proteção de direitos fundamentais.

Elaine Harzheim Macedo e Shana Serrão Fensterseifer ${ }^{10}$ apontam que o direito à tutela jurisdicional tempestiva, termo que as autoras adotam como sinônimo de duração razoável do processo, está vinculada à utilidade da prestação jurisdicional, ou seja, o processo terá duração razoável quando o tempo necessário para seu tramite não prejudicar o provimento final da demanda, não obstando a efetividade do processo. Assim, os autores tratam a tempestividade processual como condição de efetividade da prestação jurisdicional. Seguindo a mesma linha de raciocínio, Artur César de Souza ${ }^{11}$ defende que a duração razoável do processo é princípio de extrema importância, pois uma decisão intempestiva não será suficientemente útil às partes, ainda que seja favorável.

A única forma de alcançar a definição de razoável é pela análise do caso concreto, o qual, a partir de suas especificidades, demonstrará se o tempo despendido resultou em prestação jurisdicional efetiva sob os aspectos quantitativo e qualitativo. ${ }^{12}$ Causas complexas do ponto de vista fático, demandando uma instrução minuciosa e sentença bem

\footnotetext{
${ }^{7}$ MACEDO, Elaine Harzheim; CARVALHO, Volgane Oliveira. A duração razoável do processo no direito brasileiro e o novo código de processo civil: avanços e recuos. Revista Eletrônica de Direito Processual REDP, v. 15, n. 15, 2015, p. 74-106.

${ }^{8}$ MACEDO, Elaine Harzheim; FENSTERSEIFER, Shana Serrão. O direito fundamental à tutela jurisdicional tempestiva na perspectiva constitucional e o caso problemático da sentença sem eficácia imediata ope legis que tutela direito em risco de dano ou perecimento. Revista de Processo, v. 237/2014, nov/2014, p. 13-41

${ }^{9}$ MACEDO, Elaine Harzheim; CARVALHO, Volgane Oliveira, op. cit.

${ }^{10}$ MACEDO, Elaine Harzheim; FENSTERSEIFER, Shana Serrão, p. cit.

${ }^{11}$ DE SOUZA, Artur César. Celeridade processual e a máxima da razoabilidade no novo CPC (aspectos positivos e negativos do art. $4 .^{\circ}$ do novo CPC). Revista de Processo, v. 246/2015, ago/2015, p. 43-57

12 PRIEBE, Victor Saldanha; SPENGLER, Fabiana Marion. A razoável duração do processo na jurisdição brasileira. Revista Eletrônica de Direito Processual - REDP, v. 18, n. 2, 2017, p. 165-191.
} 
Rio de Janeiro. Ano 13. Volume 20. Número 3. Setembro a Dezembro de 2019

Periódico Quadrimestral da Pós-Graduação Stricto Sensu em Direito Processual da UERJ

Patrono: José Carlos Barbosa Moreira (in mem.). ISSN 1982-7636. pp. 239-267

www.redp.uerj.br

fundamentada, afetam o custo temporal da resolução da lide. Influem também na tempestividade da prestação jurisdicional, o comportamento das partes, dentre os quais se destacam a boa-fé processual e abstenção de atos protelatórios, e a atuação dos servidores públicos envolvidos, em especial, do magistrado, como condutor do processo. ${ }^{13}$

Além das especificidades do caso concreto, para se ter uma jurisdição adequada sob os aspectos quantitativo e qualitativo, é necessário atender o princípio constitucional do devido processo legal. ${ }^{14} \mathrm{O}$ processo não terá efetividade se atendido somente os princípios consagrados no artigo $5^{\circ}$, LXXVIII da Constituição Federal de 1988, sendo essencial a aplicação efetiva do devido processo legal, pois o processo é indispensável meio de garantia de princípios e direitos fundamentais e, portanto, não deve ser tratado com enfoque em seu viés instrumental. ${ }^{15}$

Francisco Glauber Pessoa Alves ${ }^{16}$ apresenta uma crítica aos juristas brasileiros, apontando o emprego de grandes esforços em conceituar o devido processo legal e meios teóricos de protegê-lo, em contraponto à situação de poucos se ocuparem em investigar recursos financeiros e materiais que viabilizariam a prestação de tutela jurisdicional em tempo razoável.

José Augusto Garcia de Sousa ${ }^{17}$ aborda a duração razoável do processo como "vetor resultante" da junção de outros vetores, dos quais se extrai a celeridade, conceituando esta como um vetor cuja função é acelerar o tramite do processo judicial. Defende que a celeridade processual e a razoável duração do processo nem sempre seriam aplicáveis ao mesmo caso, pois este demanda a aplicação de diversos outros princípios.

O princípio da celeridade processual foi incluído de forma expressa na segunda parte do art. 5, LVIII, CF/88, como já exposto. Além disso, o art. $7^{\circ}$ da EC 45/2004 prevê a promoção de "alterações na legislação federal objetivando tornar mais amplo o acesso à Justiça e mais célere a prestação jurisdicional".

\footnotetext{
${ }^{13}$ MACEDO, Elaine Harzheim; CARVALHO, Volgane Oliveira. A duração razoável do processo no direito brasileiro e o novo código de processo civil: avanços e recuos. Revista Eletrônica de Direito Processual REDP, v. 15, n. 15, 2015, p. 74-106.

${ }^{14}$ PRIEBE, Victor Saldanha; SPENGLER, Fabiana Marion, op. cit.

15 FIORATTO, Débora Carvalho. Efetividade do processo e ou razoável duração do processo no estado democrático de direito. Revista Eletrônica de Direito Processual - REDP, v. 9, n. 9, 2012, p. 90-126.

${ }^{16}$ ALVES, Francisco Glauber Pessoa. Celeridade como princípio constitucional inegável, o novo código de processo civil e os juizados especiais cíveis. Revista de Processo, v. 275/2018, jan/2018, p. 19-42.

17 DE SOUSA, José Augusto Garcia. A tríade constitucional da tempestividade do processo (em sentido amplo): celeridade, duração razoável e tempestividade estrutural. Revista de Processo, v. 280/2018, jun/2018, p. $95 / 142$
} 
Revista Eletrônica de Direito Processual - REDP.

Rio de Janeiro. Ano 13. Volume 20. Número 3. Setembro a Dezembro de 2019

Periódico Quadrimestral da Pós-Graduação Stricto Sensu em Direito Processual da UERJ

Patrono: José Carlos Barbosa Moreira (in mem.). ISSN 1982-7636. pp. 239-267

www.redp.uerj.br

O princípio da celeridade processual tem como objetivo a aceleração processual em sentido amplo, abrangendo inclusive as tutelas provisórias como forma de viabilizar o aproveitamento do direito buscado pela parte aparentemente com razão, assim, o princípio é fundamento para diversas regras processuais, dentre as quais destaca a improcedência liminar do pedido, o julgamento antecipado do mérito, a preclusão, o procedimento monitório e as tutelas provisórias. ${ }^{18}$

Apesar da garantia constitucional em norma de eficácia imediata, a efetividade da celeridade ainda parece utópica na prática do judiciário brasileiro. José Augusto Garcia de Sousa $^{19}$ aponta que os argumentos segundo os quais a celeridade não pode prejudicar garantias fundamentais são verdadeiros obstáculos à concretização desse princípio. $\mathrm{O}$ autor explica que, por ser também uma garantia fundamental processual, deveria ser realizada uma ponderação entre os princípios colidentes, podendo prevalecer a celeridade ou outra garantia a depender das peculiaridades do caso.

As garantias processuais não podem ser óbice à celeridade, viabilizando um processo quase interminável, devendo as garantias processuais serem complementares entre si. ${ }^{20}$ Assim, o magistrado deve equilibrar a necessidade de qualidade do sistema judiciário com a duração do processo, a fim de proferir decisão célere e justa, sempre considerando as especificidades do caso. Decisão célere não é sinônimo de justa, não podendo a celeridade ser um fim em si mesma. ${ }^{21}$ A razoável duração dos processos não pode ser compreendida como garantia que tutela apenas a aceleração processual. ${ }^{22}$

Elaine Harzheim Macedo e Shana Serrão Fensterseifer ${ }^{23}$ defendem que a doutrina e a jurisprudência empregam as expressões "morosidade processual" e "intempestividade processual" como sinônimos de forma equivocada. Explicam que mesmo que um processo tenha passado por fases prolongadas, sendo, portanto moroso, ainda sim poderá ser

18 DE SOUSA, José Augusto Garcia. A tríade constitucional da tempestividade do processo (em sentido amplo): celeridade, duração razoável e tempestividade estrutural. Revista de Processo, v. 280/2018, jun/2018, p. $95 / 142$.

${ }^{19}$ Ibid.

${ }^{20}$ ALVES, Francisco Glauber Pessoa. Celeridade como princípio constitucional inegável, o novo código de processo civil e os juizados especiais cíveis. Revista de Processo, v. 275/2018, jan/2018, p. 19-42

${ }^{21}$ DE SOUZA, Artur César, Celeridade processual e a máxima da razoabilidade no novo CPC (aspectos positivos e negativos do art. 4. ${ }^{\circ}$ do novo CPC). Revista de Processo, v. 246/2015, ago/2015, p. 43-57.

22 PRIEBE, Victor Saldanha; SPENGLER, Fabiana Marion. A razoável duração do processo na jurisdição brasileira. Revista Eletrônica de Direito Processual - REDP, v. 18, n. 2, 2017, p. 165-191.

23 MACEDO, Elaine Harzheim; FENSTERSEIFER, Shana Serrão. O direito fundamental à tutela jurisdicional tempestiva na perspectiva constitucional e o caso problemático da sentença sem eficácia imediata ope legis que tutela direito em risco de dano ou perecimento. Revista de Processo, v. 237/2014, nov/2014, p. 13-41 
Rio de Janeiro. Ano 13. Volume 20. Número 3. Setembro a Dezembro de 2019

Periódico Quadrimestral da Pós-Graduação Stricto Sensu em Direito Processual da UERJ

Patrono: José Carlos Barbosa Moreira (in mem.). ISSN 1982-7636. pp. 239-267

www.redp.uerj.br

tempestivo, exemplificam com a fase citatória de um processo de usucapião, procedimento editalício, e expedição de carta rogatória para oitiva de testemunha. Isto porque, diversas etapas processuais são morosas por sua natureza, contudo, somente quando a demora ultrapassar o limite necessário para que o direito almejado não seja lesado haverá intempestividade processual.

José Augusto Garcia de Sousa ${ }^{24}$ aponta que o foco da Emenda Constitucional de 2004 não foi a duração razoável do processo, mas a celeridade em si, pois os eleitores brasileiros sequer conhecem o conceito de duração razoável, almejando, em verdade, uma prestação jurisdicional mais rápida. $\mathrm{O}$ autor critica o conceito de duração razoável do processo sob o argumento de que este princípio não teria um foco específico, abrangendo tanto a aceleração do tramite processual quanto sua desaceleração. Assim, o princípio jamais seria deixado à parte, ao passo que a celeridade sofre as mais diversas restrições.

O Relatório Justiça em Números elaborado pelo Conselho Nacional de Justiça (CNJ) no ano de $2018^{25}$, referente à produtividade do ano de 2017, embasada em estatísticas judiciárias oficiais, apresenta índice de produtividade comparada da justiça (IPC-Jus) o qual pode variar de $0 \%$ a $100 \%$, refletindo a produtividade e eficiência relativas dos tribunais em único valor. $O$ índice considera a produção em função dos recursos disponíveis a cada tribunal, assim o IPC-Jus é a razão entre a produtividade real e o quanto o tribunal deveria ter produzido com os recursos dos quais dispõem para alcançar $100 \%$ de eficiência.

O IPC-Jus do TJCE em primeiro grau é $65 \%$, e no segundo grau, 47\%. O relatório demonstra ainda que o TJCE precisaria baixar 1.350 processos no ano de 2017 para atingir $100 \%$ de sua efetividade, contudo, somente foram baixados 908 .

Diante do considerável contraste entre as garantias constitucionais da razoável duração do processo e celeridade processual, de eficácia imediata, e a realidade da morosidade do Judiciário, Elaine Harzheim Macedo e Volgane Oliveira Carvalho ${ }^{26}$

\footnotetext{
${ }^{24}$ DE SOUSA, José Augusto Garcia. A tríade constitucional da tempestividade do processo (em sentido amplo): celeridade, duração razoável e tempestividade estrutural. Revista de Processo, v. 280/2018, jun/2018, p. $95 / 142$.

25 CONSELHO NACIONAL DE JUSTIÇA. Relatório Justiça em Números 2018. Disponível em: <http://www.cnj.jus.br/programas-e-acoes/pj-justica-em-numeros/relatorio>. Acesso em: 11 mar. 2019

${ }^{26}$ MACEDO, Elaine Harzheim; CARVALHO, Volgane Oliveira. A duração razoável do processo no direito brasileiro e o novo código de processo civil: avanços e recuos. Revista Eletrônica de Direito Processual REDP, v. 15, n. 15, 2015, p. 74-106
} 
Rio de Janeiro. Ano 13. Volume 20. Número 3. Setembro a Dezembro de 2019

Periódico Quadrimestral da Pós-Graduação Stricto Sensu em Direito Processual da UERJ

Patrono: José Carlos Barbosa Moreira (in mem.). ISSN 1982-7636. pp. 239-267

www.redp.uerj.br

defendem que a solução deveria passar por edição de lei que trate da matéria constitucional viabilizando sua efetividade com o estabelecimento de normas claras e objetivas.

Nesse contexto, surgiu o Código de Processo Civil de 2015 (CPC/15) tendo como um dos seus principais objetivos a promoção da celeridade processual e razoável duração do processo, conforme insculpido em seu artigo $4^{\circ}$ : "As partes têm o direito de obter em prazo razoável a solução integral do mérito, incluída a atividade satisfativa." Uma das medidas adotadas com o fim de promover a aceleração do trâmite processual foi a supressão dos embargos infringentes e inclusão da técnica de julgamento prevista no artigo $942, \mathrm{CPC} / 15$.

\section{A SUPRESSÃO DOS EMBARGOS INFRINGENTES NO CÓDIGO DE PROCESSO} CIVIL DE 2015

Os Embargos Infringentes, previstos na legislação processual brasileira até a entrada em vigor do Código de Processo Civil de 2015 em março de 2016, constituíam meio de impugnação de decisões colegiadas não unanimes. O artigo 530 do CPC/73 determinava originariamente como hipótese de cabimento deste recurso a ausência de unanimidade em julgamento proferido em sede de apelação e ação rescisória, especificando que o recurso deveria ser limitado à matéria sobre a qual recaia a divergência.

$\mathrm{O}$ instituto era alvo de constantes criticas mesmo antes da vigência do $\mathrm{CPC} / 73$, continuando a ser amplamente reprovado pela doutrina ${ }^{27}$. As criticas eram fundadas na morosidade que a oposição deste recurso trazia ao processo, causada pela ampla hipótese de cabimento prevista, a qual abrangia qualquer divergência em julgamento de apelações e ações rescisórias. $^{28}$

Apesar de reprovar os embargos infringentes, José Carlos Barbosa Moreira ${ }^{29}$ explica que, após observar a experiência do Tribunal de Justiça do Rio de Janeiro de 1978 a 1992 com este recurso, alterou seu posicionamento, passando a defender sua manutenção, desde que suas hipóteses de cabimento fossem limitadas. O autor recomendava a exclusão das seguintes situações como hipóteses de cabimento: manifestação de divergência em

${ }^{27}$ MOREIRA, José Carlos Barbosa. Novas vicissitudes dos embargos infringentes. Revista da EMERJ, v. 5, n. 20, 2002, p. 180/192.

${ }^{28}$ DE SOUSA, José Augusto Garcia. Em defesa dos embargos infringentes: reflexões sobre os rumos da grande reforma processual. Revista Eletrônica de Direito Processual - REDP, v. 5, n. 5, 2010, p. 560-613.

${ }^{29}$ MOREIRA, José Carlos Barbosa, op. cit. 
Rio de Janeiro. Ano 13. Volume 20. Número 3. Setembro a Dezembro de 2019

Periódico Quadrimestral da Pós-Graduação Stricto Sensu em Direito Processual da UERJ

Patrono: José Carlos Barbosa Moreira (in mem.). ISSN 1982-7636. pp. 239-267 www.redp.uerj.br

julgamento de preliminar, no âmbito de apelação interposta em face de sentença meramente terminativa, bem como na manutenção da sentença apelada.

O posicionamento de José Carlos Barbosa Moreira parece ter sido acolhido à época pela legislação brasileira, pois a Lei $\mathrm{n}^{\circ}$ 10.352/2001 alterou o artigo 530 do CPC/73, passando o dispositivo a apresentar a seguinte redação: "Cabem embargos infringentes quando o acórdão não unânime houver reformado, em grau de apelação, a sentença de mérito, ou houver julgado procedente ação rescisória. Se o desacordo for parcial, os embargos serão restritos à matéria objeto da divergência".

A solução apresentada pelo legislador foi elogiada por José Augusto Garcia de Sousa $^{30}$. Conforme o autor, o cabimento do recurso passou a exigir um empate de votos, considerando a posição do magistrado de primeira instância ao lado do voto vencido no julgamento do colegiado, em oposição aos votos que prevaleceram no julgamento da apelação ou ação rescisória. Destaca ainda que a oposição desse recurso passou a ser vinculada aos provimentos de mérito.

Ainda assim, os embargos infringentes eram alvos de fortes críticas. Letícia Fabel Gontijo e Jason Soares De Albergaria Neto ${ }^{31}$ defendem que, na prática, o recurso ensejava mera repetição automática de entendimentos antes manifestados pelos julgadores, com o objetivo de alcançar a admissão de eventual recurso especial ou extraordinário. Os autores argumentam que os embargos infringentes não atingiam o objetivo de aperfeiçoamento do julgamento.

Por consequência das persistentes críticas, o instituto foi extinto do processo civil brasileiro com a entrada em vigor do Código de Processo Civil de 2015, não sendo listado no rol taxativo de recursos do art. 994, CPC/15. A exposição de motivos do CPC/15 esclarece que há muito tempo a doutrina apontava para a necessidade de supressão dos embargos infringentes, e explica que, em contrapartida à sua eliminação, o relator do processo terá a obrigação de declarar o voto vencido, e este integrará o acórdão, inclusive para fins de prequestionamento. ${ }^{32}$

${ }^{30}$ DE SOUSA, José Augusto Garcia, Em defesa dos embargos infringentes: reflexões sobre os rumos da grande reforma processual. Revista Eletrônica de Direito Processual - REDP, v. 5, n. 5, 2010, p. 560-613.

${ }^{31}$ GONTIJO, Letícia Fabel; DE ALBERGARIA NETO, Jason Soares. A técnica de julgamento do art. 942 do CPC/15 e sua repercussão: pesquisa descritiva e quantitativa no âmbito do TJMG. Revista de Processo, v. 277/2018, mar 2018, p. 305/322.

${ }^{32}$ BRASIL. Exposição de Motivos do Código de Processo Civil brasileiro de 2015. Lei no 13.105 de 16 de março de 2015. Disponível em: <https://www2.senado.leg.br/bdsf/bitstream/handle/id/512422/001041135.pdf>. Acesso em: 12 mar. 2019. 
Revista Eletrônica de Direito Processual - REDP.

Rio de Janeiro. Ano 13. Volume 20. Número 3. Setembro a Dezembro de 2019

Periódico Quadrimestral da Pós-Graduação Stricto Sensu em Direito Processual da UERJ

Patrono: José Carlos Barbosa Moreira (in mem.). ISSN 1982-7636. pp. 239-267

www.redp.uerj.br

José Carlos Barbosa Moreira ${ }^{33}$ explica que no Brasil a questão da morosidade muitas vezes é atrelada ao excesso de recursos previstos pela lei processual civil, sendo esta apontada como um dos vetores mais importantes da demora no trâmite do processo. Marco Antônio dos Santos Rodrigues e Thaís Boia Marçal ${ }^{34}$ reforçam a ideia, defendendo que os embargos infringentes não atendiam o princípio da razoável duração do processo, pois no momento de sua oposição o embargante já tivera a oportunidade de exercer o contraditório e a ampla defesa nas instâncias ordinárias, prolongando a discussão de forma desnecessária.

Os autores defendem, portanto, que os embargos infringentes seriam mais uma espécie recursal em excesso no ordenamento jurídico. Por consequência, entendem que a supressão deste recurso beneficia a tempestividade da prestação jurisdicional e atende os princípios da celeridade e duração razoável do processo.

O posicionamento acima apresentado também é defendido por Rogério Lauria Marçal Tucci ${ }^{35}$, sob o argumento de que a inclusão do artigo 942 no CPC/15 melhor atende as necessidades da sociedade. Contudo, o autor destaca que a supressão de uma espécie recursal com reduzidas hipóteses de cabimento não é suficiente para alterar a realidade da morosidade processual, tal mudança demandaria uma completa reforma de paradigma.

Por sua vez, José Augusto Garcia de Sousa ${ }^{36}$, sustentava a manutenção dos embargos infringentes no sistema recursal. O autor critica a tese que aponta o sistema recursal como causa da morosidade judiciária, defendendo que este entendimento retrata uma análise superficial do sistema, sem o devido aprofundamento e observância de dados empíricos. Os recursos apresentariam, portanto, um atraso justificado ao processo, em razão do sistema de justiça adotado no país ser democrático.

O autor apresenta fundamentos para a manutenção dos embargos infringentes, dentre os quais se destacam: a supressão do recurso não apresentaria significativa redução da morosidade, pois são quantitativamente ínfimos os recursos opostos, uma vez que os

${ }^{33}$ MOREIRA, José Carlos Barbosa. Novas vicissitudes dos embargos infringentes. Revista da EMERJ, v. 5, n. 20, 2002, p. 180/192.

${ }^{34}$ RODRIGUES, Marco Antônio dos Santos; MARÇAL, Thaís Boia. Embargos infringentes e o novo CPC: manutenção ou extinção? Revista Eletrônica de Direito Processual - REDP, v. 10, n. 10, 2012, p. 326-338.

35 TUCCI, Rogério Lauria Marçal. Perfil histórico dos embargos infringentes (das ordenações afonsinas ao código de processo civil de 2015). Revista de Processo, v. 249/2015, nov 2015, p. 275/293.

${ }^{36}$ DE SOUSA, José Augusto Garcia. Em defesa dos embargos infringentes: reflexões sobre os rumos da grande reforma processual. Revista Eletrônica de Direito Processual - REDP, v. 5, n. 5, 2010, p. 560-613. 
Rio de Janeiro. Ano 13. Volume 20. Número 3. Setembro a Dezembro de 2019

Periódico Quadrimestral da Pós-Graduação Stricto Sensu em Direito Processual da UERJ

Patrono: José Carlos Barbosa Moreira (in mem.). ISSN 1982-7636. pp. 239-267

www.redp.uerj.br

desembargadores evitariam a produção de julgados não unânimes, assim, somente as reais divergências acarretariam tais julgados, reforçando a ideia de que esses embargos seriam excepcionais; o recurso viabiliza a segurança jurídica, pois viabiliza a resolução de casos de forte incerteza causados pela divergência, em especial nos casos de ações rescisórias os quais tratam da coisa julgada, elemento indispensável para a garantia da segurança jurídica; a importância dos embargos infringentes na pacificação de conflitos jurisprudenciais, viabilizando a consolidação de teses inovadoras e, portanto, colaborando com a argumentação no âmbito do processo.

\subsection{Técnica de Julgamento}

Para compensar a supressão dos embargos infringentes, o legislador incluiu o artigo 942 no $\mathrm{CPC} / 15$, instituindo a técnica de julgamento no ordenamento jurídico brasileiro. $\mathrm{O}$ dispositivo determina que em casos de possibilidade julgamento de apelação não unânime, a sessão de julgamento deverá ser adiada a fim de convocar outros julgadores em número que impossibilite a modificação do resultado, podendo ser realizada na mesma sessão se houver quórum para tanto, conforme o art. 942, § $1^{\circ}, \mathrm{CPC} / 15$.

O parágrafo terceiro do referido dispositivo determina que a técnica de julgamento é também aplicável à ação rescisória quando o resultado do julgamento for a rescisão da sentença, e ao agravo de instrumento, na hipótese de modificação da decisão de julga parcialmente o mérito.

O artigo 942 do Código de Processo Civil de 2015 não institui espécie recursal, pois a técnica de julgamento é determinação legal que deve ocorre durante o julgamento do processo. Marco Antônio dos Santos Rodrigues e Thaís Boia Marçal ${ }^{37}$, analisando a técnica de julgamento ainda no período em que este instituto constava apenas no projeto de lei em trâmite na Câmara dos Deputados, entendem que o instituto viabilizaria a simplificação do procedimento para divergências em julgamentos.

Rogério Lauria Marçal Tucci ${ }^{38}$ defende que a técnica de julgamento não traz morosidade ao trâmite processual como os embargos infringentes traziam, proporciona

\footnotetext{
${ }^{37}$ RODRIGUES, Marco Antônio dos Santos; MARÇAL, Thaís Boia. Embargos infringentes e o novo CPC: manutenção ou extinção? Revista Eletrônica de Direito Processual - REDP, v. 10, n. 10, 2012, p. 326-338.

38 TUCCI, Rogério Lauria Marçal. Perfil histórico dos embargos infringentes (das ordenações afonsinas ao código de processo civil de 2015). Revista de Processo, v. 249/2015, nov 2015, p. 275/293.
} 
Rio de Janeiro. Ano 13. Volume 20. Número 3. Setembro a Dezembro de 2019

Periódico Quadrimestral da Pós-Graduação Stricto Sensu em Direito Processual da UERJ

Patrono: José Carlos Barbosa Moreira (in mem.). ISSN 1982-7636. pp. 239-267

www.redp.uerj.br

uma melhor qualidade dos julgados em segunda instância e uniformiza a jurisprudência. Elaine Harzheim Macedo e Volgane Oliveira Carvalho ${ }^{39}$, por outro lado, entendem que a técnica de julgamento não trouxe avanço para a questão da morosidade processual, pois com o aumento da duração do julgamento, a lei teria trocado "seis por meia dúzia".

Comparando o CPC/73 e o CPC/15, percebe-se o aumento das situações que exigem a aplicação da técnica de julgamento diante das hipóteses de cabimento dos embargos infringentes, em razão da inclusão do julgamento de agravo de instrumento, em caso de reforma de decisão que julgue parcialmente o mérito, e ampliação das hipóteses para apelação, determinando a aplicação da técnica de julgamento em todos os acórdãos não unânimes.

Letícia Fabel Gontijo e Jason Soares De Albergaria Neto ${ }^{40}$ realizaram pesquisa no Tribunal de Justiça de Minas Gerais e, por meio da análise de dados, constataram que o número de julgados nos quais se aplicou a técnica de julgamento, entre 18 de março de 2016 e 28 de fevereiro de 2017, foi três vezes maior que a quantidade de embargos infringentes distribuídos entre 18 de março de 2015 e 18 de março de 2016.

A referida pesquisa demonstra que no total de 5.244 aplicações de técnica de julgamento, 5.121 foram em apelações, somente 85 em agravos de instrumento e um em ação rescisória. Letícia Fabel Gontijo e Jason Soares De Albergaria Neto ${ }^{41}$ apontam que a razão da elevada quantidade de aplicação de técnica de julgamento em apelação ocorreu em razão de a lei prever uma gama maior de hipóteses de incidência para este recurso.

Como já exposto, o artigo 942 do CPC/15 apresenta único requisito para a ampliação do colegiado em apelação: o resultado apresentado pelo julgamento inicial não ser unânime, ao passo que o parágrafo terceiro do dispositivo exige reforma de decisão que julga parcialmente o mérito para agravo de instrumento, e rescisão da sentença no caso de ação rescisória.

O artigo 942 do CPC/15 determina que a convocação de julgadores para a ampliação do colegiado deve ser realizada nos termos do regimento interno do tribunal. Verifica-se,

\footnotetext{
${ }^{39}$ MACEDO, Elaine Harzheim; CARVALHO, Volgane Oliveira. A duração razoável do processo no direito brasileiro e o novo código de processo civil: avanços e recuos. Revista Eletrônica de Direito Processual REDP, v. 15, n. 15, 2015, p. 74-106.

${ }^{40}$ GONTIJO, Letícia Fabel; DE ALBERGARIA NETO, Jason Soares. A técnica de julgamento do art. 942 do CPC/15 e sua repercussão: pesquisa descritiva e quantitativa no âmbito do TJMG. Revista de Processo, v. 277/2018, mar 2018, p. 305/322.

${ }^{41}$ Ibid.
} 
Rio de Janeiro. Ano 13. Volume 20. Número 3. Setembro a Dezembro de 2019

Periódico Quadrimestral da Pós-Graduação Stricto Sensu em Direito Processual da UERJ

Patrono: José Carlos Barbosa Moreira (in mem.). ISSN 1982-7636. pp. 239-267

www.redp.uerj.br

portanto, uma carência do $\mathrm{CPC} / 15$ quanto à determinação do procedimento a ser seguido na técnica de julgamento pois, embora os regimentos internos dos tribunais sejam incumbidos de regular a matéria, não haverá uniformidade nos procedimentos aplicados em âmbito nacional. Tendo em vista que o objeto de estudo ora realizado é o Tribunal de Justiça do Ceará, analisa-se o trâmite da técnica de julgamento prevista no Regimento Interno do Tribunal de Justiça do Ceará (RITJCE).

O artigo $80, \S 1^{\circ}$, RITJCE ${ }^{42}$, amplia o rol de aplicação de técnica de julgamento aos agravos internos e embargos de declaração, que reformam o mérito da sentença. $\mathrm{O}$ artigo 74 e V do RITJCE ${ }^{43}$ determina que a convocação de desembargadores a ampliação do colegiado siga a seguinte ordem: a câmara de direito privado deve requerer a presença de desembargador da câmara subsequente, atendendo a ordem de antiguidade, não sento possível atender a demanda, deve ser seguida a ordem das demais câmaras, para somente então requerer desembargador de câmara de diferente especialização.

Assim, o presidente da câmara da qual origina o processo expede ofício requerendo desembargador mais antigo à câmara competente de acordo com as regras acima descritas, para compor nova sessão de julgamento com aplicação de técnica de julgamento. Anexa-se ao fim do trabalho quadro 1 com comparativo entre o recurso de embargos infringentes e a técnica de julgamento.

Diante de todo o trâmite descrito, vislumbra-se a possibilidade da aplicação da técnica de julgamento implicar ao processo ônus maior que o julgamento de um novo recurso traria, pois a sessão de julgamento do recurso ou ação rescisória deve ser suspensa para a convocação de novo julgador, o qual irá adiar suas atribuições em sua Câmara originária para auxiliar o julgamento de diferente órgão colegiado.

\footnotetext{
42 Art. 80, RITJCE. O julgamento nas câmaras, que são compostas por 04 (quatro) desembargadores, será sempre tomado pelo voto de 03 (três) destes. (...) $\S 1^{\circ}$. Quando, em matéria cível, não houver resultado unânime na apelação, no agravo interno e nos embargos de declaração que reformar a sentença no seu mérito, a convocação para os fins do artigo 942 do Código de Processo Civil recairá, se possível, sobre os demais integrantes do órgão julgador. Do contrário, observar-se-ão as regras previstas no capítulo "DAS SUBSTITUIÇÕES" deste Regimento, assegurado às partes e a eventuais terceiros o direito de sustentar oralmente suas razões perante o novo julgador.

${ }^{43}$ Art. 74, RITJCE. A insuficiência de quorum para julgamento em órgão do Tribunal de Justiça, ensejada por suspeição, impedimento ou outro motivo, será suprida da seguinte forma: (...) V. nas câmaras: por desembargador da câmara subsequente, de mesma especialização, respeitada, preferencialmente a ordem de antiguidade: a) persistindo a insuficiência de quorum, passar-se-á, pela ordem, para as demais câmaras do mesmo grupo daquela na qual se dará a substituição, respeitada, preferencialmente, a ordem de antiguidade dos membros de cada órgão julgador; b) não havendo substituto, passar-se-á para as câmaras de diferente especialização, observada, preferencialmente, a ordem de antiguidade dos integrantes do órgão julgador
} 


\subsection{Possíveis consequências do art. 942 do Código de Processo Civil: ampliação das hipóteses de nova discussão quanto ao voto vencido?}

A partir da discussão doutrinária que divide opiniões entre os favoráveis à supressão dos Embargos Infringentes e os que defendiam sua manutenção, buscou-se analisar perante o Tribunal de Justiça do Ceará (TJCE) as consequências concretas que a substituição dos embargos infringentes pelas técnicas de julgamento acarretou ao tribunal, no tocante á quantidade de discussões sobre o voto vencido e o tempo de tramitação, a ser analisado no tópico seguinte.

Foi desenvolvida uma pesquisa de campo junto ao Tribunal de Justiça do Ceará, perante a Secretaria Judiciária, a Superintendência Judiciária e as quatro Câmaras de Direito Privado - as quais tratam de matéria cível. Na primeira, foi realizado um requerimento por meio de processo administrativo a respeito de informações sobre quais foram os embargos infringentes opostos e julgados desde 2014 até a entrada em vigor do Código de Processo Civil de 2015 em 16 de março de 2016. O marco inicial adotado foi o ano de 2014, pois será realizada uma analise comparativa dos institutos, assim, o ano anterior à entrada em vigor do CPC/15 é adequado os fins ora buscados.

Dentre os números de apresentados em resposta, foram excluídos três, pois não se tratavam de embargos infringentes. Verificou-se, assim, que treze embargos infringentes foram opostos e julgados desde o ano de 2014 até a entrada em vigência do CPC/15, dentre os quais, apenas quatro foram efetivamente opostos a partir deste ano, os demais já estavam pendentes de julgamento e foram apreciados neste período.

Na Superintendência Judiciária foram solicitados dados a respeito da aplicação da técnica de julgamento nas ações rescisórias, em resposta, foi obtida a informação de que o artigo 945 do CPC/15 ainda não foi aplicado a nenhuma ação rescisória.

Nas Câmaras de Direito Privado foram solicitadas informações no tocante aos demais processos aos quais foram aplicados o instituto da técnica de julgamento, após sua entrada em vigência do Código de Processo Civil de 2015, bem como o número dos processos para fins de análise do conteúdo dos processos e dados que será apresentado no tópico seguinte.

As quatro Câmaras de Direito Privado forneceram ofícios contendo os números dos processos nos quais foram utilizados a técnica de julgamento, todavia nem todos foram 
Rio de Janeiro. Ano 13. Volume 20. Número 3. Setembro a Dezembro de 2019

Periódico Quadrimestral da Pós-Graduação Stricto Sensu em Direito Processual da UERJ

Patrono: José Carlos Barbosa Moreira (in mem.). ISSN 1982-7636. pp. 239-267

www.redp.uerj.br

utilizados para os fins desta pesquisa, pois alguns ofícios dizem respeito a convocação de outro desembargador para fins de composição de quórum mínimo para instaurar sessão de julgamento, bem como aqueles em que foram convocados desembargadores que compuseram nos termos do art. 942 do CPC/15 e em razão do adiamento do julgamento precisaram comparecer novamente em momento posterior ao julgamento.

Excluíram-se ainda, para os fins desta pesquisa, os números de processos informados referentes a Embargos de Declaração nos quais foram convocados desembargadores nos termos do art. 942 do CPC para o julgamento do processo embargado e assim eles precisariam comparecer ao julgamento dos embargos, mas não para os fins da técnica de julgamento, de pacificação do entendimento. Assim, foram descartados os ofícios destas hipóteses, servindo apenas aqueles processos nos quais efetivamente foram utilizados a técnica de julgamento nos conformes do que dita o artigo do CPC/15.

Verificou-se, portanto, que desde a vigência do CPC/15 até o fechamento da presente pesquisa (março de 2019), a técnica de julgamento, prevista no artigo 942 do CPC/15, foi aplicada ao total de cinquenta e um processos. Quantitativo muito maior que os quatro embargos infringentes opostos no ano anterior à vigência do $\mathrm{CPC} / 15$, e ainda, consideravelmente maior que os treze julgados naquele período.

Os dados apresentados demonstram que a substituição dos Embargos Infringentes pelas técnicas de julgamento ampliou consideravelmente a discussão em relação ao voto vencido em recursos com possibilidade de julgamento divergente no Tribunal de Justiça do Ceará. Embora José Augusto Garcia de Sousa, tenha se manifestado favorável à manutenção dos embargos infringentes, com fundamento da garantia da segurança jurídica e na pacificação de conflitos jurisprudenciais, conforme exposto, os dados demonstram que a técnica de julgamento instituída pelo CPC/15 viabiliza uma maior resolução de divergências, ampliando a discussão a respeito da matéria controvertida, promovendo a pacificação dos conflitos de entendimentos entre os julgadores.

\section{PRESTIGIAR A DIVERGÊNCIA OU PROMOVER A CELERIDADE?}

Neste último tópico do trabalho, será analisado o tempo de tramitação que a utilização da técnica de julgamento acresceu ao trâmite dos recursos nos quais fora utilizados, para ao final, após comparar-se com os dados levantados no tópico anterior e 
Rio de Janeiro. Ano 13. Volume 20. Número 3. Setembro a Dezembro de 2019

Periódico Quadrimestral da Pós-Graduação Stricto Sensu em Direito Processual da UERJ

Patrono: José Carlos Barbosa Moreira (in mem.). ISSN 1982-7636. pp. 239-267

www.redp.uerj.br

possibilitar a conclusão do entendimento de qual instituto jurídico mostra-se mais adequado dentro da ótica desta pesquisa, para determinar-se o melhor efeito, se o da celeridade ou a promoção da divergência.

Para melhor analise dos dados, foram organizados os julgados filtrados nos quesitos acima, em quadro 2 em anexo, distribuindo-se em colunas que indicam o número do processo, a data da convocação do desembargador ou a que fora aplicada a técnica de julgamento $^{44}$, a data de julgamento do processo, o tempo que esse procedimento acrescentou ao trâmite do recurso e por fim qual decisão prevaleceu, o voto da divergência ou o voto do relator original.

Do total de processos que se destinam aos fins desta pesquisa, atingiu-se um conjunto de 51 processos, representando um total quantitativo de $100 \%$ computados desde o ano de entrada em vigor do Código de Processo Civil de 2015 até o momento de desenvolvimento desta pesquisa, março de 2019.

Do total de 51 processos, obteve-se um total de 37 processos nos quais prevaleceram o voto do Relator, tendo o desembargador convocado acompanhado seu entendimento (em alguns casos), representando um montante aproximado de $72,55 \%$ do conjunto total; ao passo que $27,45 \%$ representa o total dos processos em que houve a prevalência do voto divergente, tendo o desembargador convocado acompanhado tal entendimento.

Ainda foi possível extrair-se dos dados coletados e compilados no quadro 2, dados concernentes ao tempo que fora acrescido na tramitação de cada processo, elencados em coluna. Tendo em vista que o tempo total varia para cada processo, estabeleceu-se um critério de aproximação para estabelecerem-se subconjuntos. Para os processos em que a adoção desse procedimento acrescentou-se mais de 10 dias e menos de 20 , à sua tramitação alocou-se para o conjunto que representa o valor aproximado de 15 dias, equivalendo ao total de $24,44 \%$ do total de 45 processos (visto que em 6 processos não constava nos autos algumas das datas necessárias para o computado deste lapso temporal, excluindo-se deste cálculo, portanto); para os processos que tiveram um tempo de tramitação acrescido em aproximadamente 1 mês obteve-se o total de 15 (quinze) equivalendo a 33,33\% do total; $24,44 \%$ (11 processos) tiveram um tempo a mais de aproximadamente 2 meses; 6,66\% (3

\footnotetext{
${ }^{44}$ O Critério dependerá dos dados fornecidos por cada câmara de direito privado ou das informações contidas no processo, pois em alguns deles há a data em que fora expedido ofício ao desembargador convocado e em outras tão somente a data em que fora aplicado o disposto no art. 942 do Código de Processo Civil.
} 
Rio de Janeiro. Ano 13. Volume 20. Número 3. Setembro a Dezembro de 2019

Periódico Quadrimestral da Pós-Graduação Stricto Sensu em Direito Processual da UERJ

Patrono: José Carlos Barbosa Moreira (in mem.). ISSN 1982-7636. pp. 239-267

www.redp.uerj.br

processos) dos processos tiveram um aumento de 7 dias (1 semana) na sua tramitação; 4,44 $\%$ ( 2 processos) tiveram um tempo de 6 meses e outros 2,2\% de 2 anos ( 1 processo).

Dando continuidade à analise dos dados coletados no desenvolvimento desta pesquisa, organizou-se ainda quadro 3 contendo a relação dos processos de embargos infringentes processados e julgados até o presente momento, organizando-os em colunas com, respectivamente, o número do processo, a data da autuação do processo e a data do julgamento, bem como o tempo de tramitação do recurso, o lapso temporal entre essas duas datas.

Aproximadamente $80 \%$ por cento dos processos elencados tiveram uma tramitação aproximada entre um período demais de 1 ano até menos de 5 anos e em $20 \%$ dos processos houve uma tramitação superior a 10 anos, o que provoca, sem dúvidas uma morosidade excessiva na prestação jurisdicional, ferindo frontalmente o princípio elementar do devido processo legal, o de uma tutela que satisfaça prontamente os anseios das partes, não só prestação em si, mas dentro de um período de tempo razoável que não torne inócua a prestação jurisdicional.

O que demonstra à margem de qualquer dúvida que a adoção do instituto da técnica de julgamento trouxe uma celeridade muito maior à prestação da tutela jurisdicional, pois quando comparado o tempo que cada um dos institutos, em épocas distintas, acrescentam até a obtenção do resultado final do processo, mostra-se exorbitante e destoante entre os dados acima apresentados, sem olvidar ainda, para a obtenção do fim colimado na norma, qual seja, de uniformização das decisões, vez que em $68,5 \%$ prevaleceu o voto do Relator originariamente proferido. Mesmo que não tenham incorrido em decisões unânimes propriamente ditas, sem a existência de uma divergência, a celeridade processual mostra-se sobremaneira respeitada quando da adoção das técnicas de julgamento, mostrando-se a medida mais consentânea com os escopos do processo civil atualmente.

\section{CONCLUSÃO}

Conclui-se, portanto, que as garantias da razoável duração do processo e da celeridade processual são direitos fundamentais garantidos pelo artigo $5^{\circ}$, LLXXVIII, da $\mathrm{CF} / 88$. O primeiro consiste da garantia de que o processo tenha duração suficiente de modo a viabilizar que a tutela jurisdicional seja eficiente e, ao mesmo tempo, atenda às 
Rio de Janeiro. Ano 13. Volume 20. Número 3. Setembro a Dezembro de 2019

Periódico Quadrimestral da Pós-Graduação Stricto Sensu em Direito Processual da UERJ

Patrono: José Carlos Barbosa Moreira (in mem.). ISSN 1982-7636. pp. 239-267

www.redp.uerj.br

demais garantias individuais e processuais, tuteladas pelo princípio do devido processo legal.

Paralela à razoável duração do processo, a garantia da celeridade processual objetiva o atendimento ao direito pleiteado de forma célere, seja da apreciação final da demanda, ou da análise de tutela de urgência. A garantia não exclui outros direitos fundamentais, os quais obstam sua completa efetividade, em razão da necessidade de ponderação entre os princípios colidentes, uma vez que não pode uma garantia prevalecer com completa exclusão da outra.

Verificou-se ainda que os embargos infringentes consistem em modalidade recursal prevista pelo revogado CPC/73, aplicável em face de decisões não unânimes proferidas em apelação, em caso de acórdão não unânime que pretendesse reformar a sentença de mérito; e ação rescisória, caso acórdão divergente pretendesse julgá-la procedente.

Objetivando conferir maior efetividade às garantias da razoável duração do processo e da celeridade processual, o $\mathrm{CPC} / 15$ substituiu o referido recurso pela técnica de julgamento, o qual consiste em um procedimento consistente na convocação de julgadores em número suficiente para garantir a possibilidade de inversão do resultado inicial, devendo ser aplicado ao julgamento de apelação não unânime; ação rescisória quando o julgado rescindir a sentença; agravo de instrumento, caso haja reforma de decisão que julgue parcialmente o mérito. O RITJCE estende sua aplicação a agravo interno com resultado não unânime e embargos de declaração que reformam o mérito da sentença.

Apurou-se que desde a entrada em vigor do CPC/15 (março de 2016) até o fechamento da presente pesquisa em março de 2019, a técnica de julgamento, foi aplicada ao total de cinquenta e um processos, quantia muito maior que os treze embargos infringentes opostos do ano de 2014 até a vigência do CPC/15. A substituição dos Embargos Infringentes pelas técnicas de julgamento ampliou consideravelmente a discussão em relação ao voto vencido em recursos com possibilidade de julgamento divergente no Tribunal de Justiça do Ceará, viabilizando um aumento na resolução de divergências e promovendo a pacificação dos conflitos de entendimentos entre os julgadores.

Da analise da diferença do tempo de tramitação dos embargos infringentes e o tempo necessário para a aplicação da técnica de julgamento, verificou-se que o instituto previsto pelo art. 942, CPC/15 viabiliza um processo muito mais célere que não depende do 
processamento de outro recurso cujo trâmite pode em muito prejudicar a efetividade da prestação pelo decurso desarrazoado do tempo.

\section{REFERÊNCIAS}

ALVES, Francisco Glauber Pessoa. Celeridade como princípio constitucional inegável, o novo código de processo civil e os juizados especiais cíveis. Revista de Processo, v. 275/2018, jan/2018, p. 19-42.

BRASIL. Constituição (1988). Constituição da República Federativa do Brasil, Brasília, DF, Senado, 1988.

BRASIL. Exposição de Motivos do Código de Processo Civil brasileiro de 2015. Lei n ${ }^{\circ}$ 13.105 de 16 de março de 2015. Disponível em: <https://www2.senado.leg.br/bdsf/bitstream/handle/id/512422/001041135.pdf>. Acesso em: 12 mar. 2019.

BRASIL. Lei no 5.869 de 11 de janeiro de 1973. Código de Processo Civil brasileiro de 1973. Brasília, DF, Senado, 1973.

BRASIL. Lei no 13.105 de 16 de março de 2015. Código de Processo Civil brasileiro de 2015. Brasília, DF, Senado, 2015.

CEARÁ. Regimento Interno do Tribunal de Justiça do Estado do Ceará. Fortaleza, 2018. Disponível em: <https://www.tjce.jus.br/wpcontent/uploads/2015/07/Regimento-Interno-TJCE-2018-28Miolo29-Final.pdf>. Acesso em: 12 mar. 2019.

CONSELHO NACIONAL DE JUSTIÇA. Relatório Justiça em Números 2018. Disponível em: <http://www.cnj.jus.br/programas-e-acoes/pj-justica-emnumeros/relatorio>. Acesso em: 11 mar. 2019.

DE SOUSA, José Augusto Garcia. A tríade constitucional da tempestividade do processo (em sentido amplo): celeridade, duração razoável e tempestividade estrutural. Revista de Processo, v. 280/2018, jun/2018, p. 95/142.

DE SOUSA, José Augusto Garcia. Em defesa dos embargos infringentes: reflexões sobre os rumos da grande reforma processual. Revista Eletrônica de Direito Processual REDP, v. 5, n. 5, 2010, p. 560-613. Disponível em: < https://www.e- 
Rio de Janeiro. Ano 13. Volume 20. Número 3. Setembro a Dezembro de 2019 Periódico Quadrimestral da Pós-Graduação Stricto Sensu em Direito Processual da UERJ

Patrono: José Carlos Barbosa Moreira (in mem.). ISSN 1982-7636. pp. 239-267

www.redp.uerj.br

publicacoes.uerj.br/index.php/redp/article/view/23104/16457>. Acesso em: 12 mar 2019.

DE SOUZA, Artur César. Celeridade processual e a máxima da razoabilidade no novo cpc (aspectos positivos e negativos do art. $4 .^{\circ}$ do novo CPC). Revista de Processo, v. 246/2015, ago/2015, p. 43-57.

FIORATTO, Débora Carvalho. Efetividade do processo e ou razoável duração do processo no estado democrático de direito. Revista Eletrônica de Direito Processual REDP, v. 9, n. 9, 2012, p. 90-126.

GONTIJO, Letícia Fabel; DE ALBERGARIA NETO, Jason Soares. A técnica de julgamento do art. 942 do CPC/15 e sua repercussão: pesquisa descritiva e quantitativa no âmbito do TJMG. Revista de Processo, v. 277/2018, mar 2018, p. $305 / 322$.

MACEDO, Elaine Harzheim; CARVALHO, Volgane Oliveira. A duração razoável do processo no direito brasileiro e o novo código de processo civil: avanços e recuos. Revista Eletrônica de Direito Processual - REDP, v. 15, n. 15, 2015, p. 74-106.

MACEDO, Elaine Harzheim; FENSTERSEIFER, Shana Serrão. O direito fundamental à tutela jurisdicional tempestiva na perspectiva constitucional e o caso problemático da sentença sem eficácia imediata ope legis que tutela direito em risco de dano ou perecimento. Revista de Processo, v. 237/2014, nov/2014, p. 13-41.

MOREIRA, José Carlos Barbosa. Novas vicissitudes dos embargos infringentes. Revista da EMERJ, v. 5, n. 20, 2002, p. 180/192.

Organização dos Estados Americanos. Convenção Americana de Direitos

Humanos ("Pacto de San José de Costa Rica"), 1969. Disponível em: <https://www.cidh.oas.org/basicos/portugues/c.convencao_americana.htm>. Acesso em: 11 mar. 2019.

PRIEBE, Victor Saldanha; SPENGLER, Fabiana Marion. A razoável duração do processo na jurisdição brasileira. Revista Eletrônica de Direito Processual - REDP, v. 18, n. 2, 2017, p. 165-191.

RODRIGUES, Marco Antônio dos Santos; MARÇAL, Thaís Boia. Embargos infringentes e o novo CPC: manutenção ou extinção? Revista Eletrônica de Direito Processual - REDP, v. 10, n. 10, 2012, p. 326-338. 
Rio de Janeiro. Ano 13. Volume 20. Número 3. Setembro a Dezembro de 2019

Periódico Quadrimestral da Pós-Graduação Stricto Sensu em Direito Processual da UERJ

Patrono: José Carlos Barbosa Moreira (in mem.). ISSN 1982-7636. pp. 239-267 www.redp.uerj.br

\begin{abstract}
TUCCI, Rogério Lauria Marçal. Perfil histórico dos embargos infringentes (das ordenações afonsinas ao código de processo civil de 2015). Revista de Processo, v. 249/2015, nov 2015 , p. $275 / 293$.
\end{abstract}

Quadro1: Comparativo entre as características dos embargos infringentes e as técnicas de julgamento.

\begin{tabular}{|l|l|}
\hline \multicolumn{1}{|c|}{ Embargos Infringentes (CPC/73) } & \multicolumn{1}{|c|}{ Técnica de Julgamento (CPC/15) } \\
\hline $\begin{array}{l}\text { Oposição de recurso de embargos } \\
\text { infringentes. }\end{array}$ & $\begin{array}{l}\text { Não há necessidade de oposição de recurso, } \\
\text { pois ocorre durante o julgamento do processo. }\end{array}$ \\
\hline $\begin{array}{l}\text { Voluntariedade. } \\
\text { Oportuniza-se a apresentação de } \\
\text { contrarrazões. }\end{array}$ & $\begin{array}{l}\text { Oportuniza-se a realização de sustentação oral } \\
\text { perante os novos julgadores. }\end{array}$ \\
\hline $\begin{array}{l}\text { Resolve-se a divergência pelo julgamento } \\
\text { do recurso. }\end{array}$ & $\begin{array}{l}\text { Resolve-se a divergência pela convocação de } \\
\text { novos julgadores em número suficiente para } \\
\text { garantir a possibilidade de inversão do } \\
\text { resultado inicial. }\end{array}$ \\
\hline $\begin{array}{l}\text { Cabível em: a) apelação, em caso de } \\
\text { acórdão não unânime que pretendesse } \\
\text { reformar a sentença de mérito; b) ação } \\
\text { rescisória, caso acórdão divergente } \\
\text { pretendesse julgá-la procedente. }\end{array}$ & $\begin{array}{l}\text { Deve ocorrer no julgamento de: a) apelação } \\
\text { não unânime; b) ação rescisória quando o } \\
\text { julgado rescindir a sentença; c) agravo de } \\
\text { instrumento, caso haja reforma de decisão que } \\
\text { julgue parcialmente o mérito. No TJCE, } \\
\text { acrescenta-se: a) agravo interno com resultado } \\
\text { não unânime; b) embargos de declaração que } \\
\text { reformamo mérito da sentença. }\end{array}$ \\
\hline
\end{tabular}

Fonte: Elaboração própria, 2019.

Quadro2: Análise dos processos aos quais foram aplicados a técnica de julgamento.

\begin{tabular}{|c|c|c|c|c|}
\hline & Data de & Data de & Resultado & Tempo de \\
convocação do & julgamento & $\begin{array}{c}\text { (Divergência } \\
\text { tramitação }\end{array}$ \\
\hline
\end{tabular}


Revista Eletrônica de Direito Processual - REDP.

Rio de Janeiro. Ano 13. Volume 20. Número 3. Setembro a Dezembro de 2019

Periódico Quadrimestral da Pós-Graduação Stricto Sensu em Direito Processual da UERJ

Patrono: José Carlos Barbosa Moreira (in mem.). ISSN 1982-7636. pp. 239-267

www.redp.uerj.br

\begin{tabular}{|c|c|c|c|c|}
\hline & desembargador & & $\begin{array}{l}\text { ou voto com } \\
\text { o Relator) }\end{array}$ & (aproximado) \\
\hline $\begin{array}{c}\text { 0000923- } \\
\text { 32.2007.8.06.0036 }\end{array}$ & $22 / 06 / 2016$ & $13 / 12 / 2017$ & Relator & 6 meses \\
\hline $\begin{array}{c}\text { 0621374- } \\
\text { 88.2017.8.06.0000 }\end{array}$ & 05/01/2016 & $08 / 02 / 2018$ & Relator & 2 anos \\
\hline $\begin{array}{c}\text { 0122045- } \\
\text { 83.2009.8.06.0001 }\end{array}$ & $04 / 04 / 2017$ & $18 / 04 / 2017$ & Relator & 15 dias \\
\hline $\begin{array}{c}\text { 018549- } \\
\text { 94.2012.8.06.0034 }\end{array}$ & 29/09/2017 & $17 / 10 / 17$ & Relator & 15 dias (20) \\
\hline $\begin{array}{c}\text { 0741683- } \\
\text { 34.2000.8.06.0001 }\end{array}$ & 07/08/2017 & $21 / 08 / 2017$ & Divergência & 15 dias \\
\hline $\begin{array}{c}\text { 0078342- } \\
95.2005 .8 .06 .0001\end{array}$ & $11 / 02 / 2019$ & $12 / 03 / 2019$ & Divergência & 1 mês \\
\hline $\begin{array}{c}\text { 0005404- } \\
\text { 45.2013.8.06.0095 }\end{array}$ & $27 / 07 / 2016$ & $14 / 09 / 2016$ & Relator & 2 meses \\
\hline $\begin{array}{c}\text { 0005213- } \\
\text { 97.2013.8.06.0095 }\end{array}$ & 27/07/2016 & $14 / 09 / 2016$ & Relator & 2 meses \\
\hline $\begin{array}{c}\text { 0005410- } \\
\text { 52.2013.8.06.0095 }\end{array}$ & $27 / 07 / 2016$ & $14 / 09 / 2016$ & Relator & 2 meses \\
\hline $\begin{array}{c}\text { 0624642- } \\
\text { 24.2015.8.06.0000 }\end{array}$ & & 19/10/2016 & Relator & - \\
\hline $\begin{array}{c}\text { 0149162- } \\
\text { 73.2013.8.06.0001 }\end{array}$ & $17 / 08 / 2016$ & & Divergência & - \\
\hline $\begin{array}{c}0599550- \\
\text { 66.2000.8.06.0001 }\end{array}$ & $14 / 09 / 2016$ & $19 / 10 / 2016$ & Relator & 1 mês \\
\hline $\begin{array}{c}\text { 0217115- } \\
\text { 54.2013.8.06.0001 }\end{array}$ & $21 / 09 / 2016$ & $26 / 10 / 2016$ & Relator & 1 mês \\
\hline $\begin{array}{c}\text { 0156565- } \\
\text { 93.2013.8.06.0001 }\end{array}$ & $14 / 12 / 2016$ & $22 / 02 / 2017$ & Divergência & 1 mês \\
\hline 0161685- & $14 / 12 / 2016$ & $22 / 02 / 2017$ & Divergência & 1 mês \\
\hline
\end{tabular}


Revista Eletrônica de Direito Processual - REDP.

Rio de Janeiro. Ano 13. Volume 20. Número 3. Setembro a Dezembro de 2019

Periódico Quadrimestral da Pós-Graduação Stricto Sensu em Direito Processual da UERJ

Patrono: José Carlos Barbosa Moreira (in mem.). ISSN 1982-7636. pp. 239-267

www.redp.uerj.br

\begin{tabular}{|c|c|c|c|c|}
\hline 20.2013.8.06.0001 & & & & \\
\hline $\begin{array}{c}\text { 0127543- } \\
\text { 19.2014.8.06.0001 }\end{array}$ & $14 / 12 / 2016$ & $22 / 02 / 2017$ & Relator & 1 mês \\
\hline $\begin{array}{c}\text { 0011241- } \\
\text { 92.2015.8.06.0101 }\end{array}$ & 08/02/2017 & $22 / 02 / 2017$ & Divergência & 15 dias \\
\hline $\begin{array}{c}0001374- \\
\text { 70.2016.8.06.0043 }\end{array}$ & $\begin{array}{c}\text { Não consta nos } \\
\text { autos }\end{array}$ & $22 / 02 / 2017$ & Relator & - \\
\hline $\begin{array}{c}\text { 0205271- } \\
\text { 10.2013.8.06.0001 }\end{array}$ & $15 / 03 / 2017$ & & Relator & - \\
\hline $\begin{array}{c}\text { 0201286- } \\
\text { 33.2013.8.06.0001 }\end{array}$ & $22 / 02 / 2017$ & $03 / 05 / 2017$ & Relator & 2 meses \\
\hline $\begin{array}{c}\text { 0142656- } \\
\text { 13.2015.8.06.0001 }\end{array}$ & $19 / 04 / 2017$ & $03 / 05 / 2017$ & Divergência & 15 dias \\
\hline $\begin{array}{c}\text { 0154942- } \\
\text { 23.2015.8.06.0001 }\end{array}$ & $\begin{array}{c}\text { Não consta nos } \\
\text { autos }\end{array}$ & $03 / 05 / 2017$ & Relator & - \\
\hline $\begin{array}{c}\text { 0125965- } \\
\text { 84.2016.8.06.0001 }\end{array}$ & $17 / 05 / 2017$ & $31 / 05 / 2017$ & Relator & 15 dias \\
\hline $\begin{array}{c}\text { 0877770- } \\
\text { 06.2014.8.06.0001 }\end{array}$ & $17 / 05 / 2017$ & $31 / 05 / 2017$ & Relator & 15 dias \\
\hline $\begin{array}{c}\text { 0142675- } \\
\text { 19.2015.8.06.0001 }\end{array}$ & $17 / 05 / 2017$ & $31 / 05 / 2017$ & Relator & 15 dias \\
\hline $\begin{array}{c}\text { 062100- } \\
\text { 57.2017.8.06.0000/5000 }\end{array}$ & $28 / 06 / 2017$ & $23 / 08 / 2017$ & Relator & 2 meses \\
\hline $\begin{array}{c}\text { 06226191- } \\
\text { 35.2016.8.06.0000/5000 }\end{array}$ & $28 / 06 / 2017$ & $23 / 08 / 2017$ & Divergência & 2 meses \\
\hline $\begin{array}{c}\text { 0084179- } \\
\text { 46.2014.8.06.0001 }\end{array}$ & $\begin{array}{c}\text { Não consta nos } \\
\text { autos }\end{array}$ & $03 / 05 / 2017$ & Divergência & - \\
\hline $\begin{array}{c}\text { 0873054- } \\
\text { 33.2014.8.06.0001 }\end{array}$ & $27 / 09 / 2017$ & $25 / 10 / 2017$ & Relator & 1 mês \\
\hline $\begin{array}{c}\text { 0152433- } \\
\text { 22.2015.8.06.0001 }\end{array}$ & $27 / 09 / 2017$ & $25 / 10 / 2017$ & Relator & 1 mês \\
\hline
\end{tabular}


Revista Eletrônica de Direito Processual - REDP.

Rio de Janeiro. Ano 13. Volume 20. Número 3. Setembro a Dezembro de 2019

Periódico Quadrimestral da Pós-Graduação Stricto Sensu em Direito Processual da UERJ

Patrono: José Carlos Barbosa Moreira (in mem.). ISSN 1982-7636. pp. 239-267

www.redp.uerj.br

\begin{tabular}{|c|c|c|c|c|}
\hline $\begin{array}{c}\text { 097204- } \\
\text { 75.2015.8.06.0034 }\end{array}$ & $23 / 08 / 2017$ & $06 / 10 / 2017$ & Relator & 1 mês \\
\hline $\begin{array}{c}\text { 0622229- } \\
\text { 67.2017.8.06.0000 }\end{array}$ & $28 / 02 / 2017$ & $28 / 03 / 2017$ & Relator & 1 mês \\
\hline $\begin{array}{c}\text { 0012120- } \\
\text { 13.2016.8.06.0086 }\end{array}$ & $25 / 04 / 2018$ & $02 / 05 / 2018$ & Relator & 7 dias \\
\hline $\begin{array}{c}\text { 0048607- } \\
\text { 98.2014.8.06.167 }\end{array}$ & $23 / 05 / 2018$ & $30 / 05 / 2018$ & Divergência & 7 dias \\
\hline $\begin{array}{c}\text { 0866667- } \\
\text { 02.2014.8.06.0001/5000 }\end{array}$ & $23 / 05 / 2018$ & 06/06/2018 & Divergência & 1 mês \\
\hline $\begin{array}{c}\text { 0118178- } \\
\text { 33.2018.8.06.0001 }\end{array}$ & $19 / 09 / 2018$ & $10 / 10 / 2018$ & Relator & 1 mês \\
\hline $\begin{array}{c}0150054- \\
40.2017 .8 .06 .0001\end{array}$ & $03 / 10 / 2018$ & $10 / 10 / 2018$ & Divergência & 7 dias \\
\hline $\begin{array}{c}\text { 0006284- } \\
\text { 52.2016.8.06.0153/0000 }\end{array}$ & 19/09/2018 & $10 / 10 / 2018$ & Relator & 1 mês \\
\hline $\begin{array}{c}\text { 0001361- } \\
\text { 15.2008.8.06.0136 }\end{array}$ & 05/07/2017 & 19/07/2017 & Relator & 15 dias \\
\hline $\begin{array}{c}00044755- \\
\text { 21.2013.8.06.0064 }\end{array}$ & 19/07/2017 & $08 / 11 / 2017$ & Divergência & 3 meses \\
\hline $\begin{array}{c}\text { 0046348- } \\
\text { 17.2015.8.06.0064 }\end{array}$ & $02 / 08 / 2017$ & $30 / 08 / 2017$ & Relator & 1 mês \\
\hline $\begin{array}{c}\text { 0194308- } \\
\text { 40.2013.8.06.0001 }\end{array}$ & $23 / 08 / 2017$ & $28 / 02 / 2018$ & Relator & 6 meses \\
\hline $\begin{array}{c}\text { 0207470- } \\
\text { 05.2013.8.06.0001 }\end{array}$ & $23 / 08 / 2017$ & $08 / 11 / 2017$ & Relator & 2 meses \\
\hline $\begin{array}{c}\text { 0628953- } \\
\text { 80.2000.8.06.0001 }\end{array}$ & $12 / 09 / 2017$ & $08 / 11 / 2017$ & Relator & 2 meses \\
\hline $\begin{array}{c}\text { 0190983- } \\
\text { 57.2013.8.06.0001 }\end{array}$ & $16 / 05 / 2018$ & $30 / 05 / 2018$ & Relator & 15 dias \\
\hline 0111668- & $30 / 05 / 2018$ & $04 / 07 / 2018$ & Divergência & 1 mês \\
\hline
\end{tabular}


Revista Eletrônica de Direito Processual - REDP.

Rio de Janeiro. Ano 13. Volume 20. Número 3. Setembro a Dezembro de 2019

Periódico Quadrimestral da Pós-Graduação Stricto Sensu em Direito Processual da UERJ

Patrono: José Carlos Barbosa Moreira (in mem.). ISSN 1982-7636. pp. 239-267

www.redp.uerj.br

\begin{tabular}{|c|c|c|c|c|}
\hline \hline $\begin{array}{c}\text { 38.2017.8.06.0001 } \\
\text { 0000227- } \\
\text { 75.2002.8.06.0034 }\end{array}$ & $05 / 12 / 2018$ & $30 / 01 / 2019$ & Relator & 2 meses \\
\hline $\begin{array}{c}\text { 0000674- } \\
\text { 63.2002.8.06.0034 }\end{array}$ & $05 / 12 / 2018$ & $30 / 01 / 2019$ & Relator & 2 meses \\
\hline $\begin{array}{c}\text { 0115960- } \\
\text { 32.2018.8.06.0001 }\end{array}$ & $30 / 01 / 2019$ & $27 / 03 / 2019$ & Relator & 2 meses \\
\hline $\begin{array}{c}\text { 0885193- } \\
\text { 17.2014.8.06.0001 }\end{array}$ & $13 / 03 / 2019$ & $27 / 03 / 2019$ & Relator & 15 dias \\
\hline $\begin{array}{c}\mathbf{0 2 1 1 9 5 0 -} \\
\mathbf{5 5 . 2 0 1 5 . 8 . 0 6 . 0 0 0 1}\end{array}$ & $24 / 04 / 2019$ & $08 / 05 / 2019$ & Relator & 15 dias \\
\hline
\end{tabular}

Fonte: Elaboração própria, 2019.

Quadro3: Análise dos embargos infringentes.

\begin{tabular}{|c|c|c|c|c|}
\hline $\mathrm{N}^{\circ}$ do Processo & $\begin{array}{c}\text { Data de } \\
\text { oposição dos } \\
\text { embargos }\end{array}$ & $\begin{array}{c}\text { Data de } \\
\text { julgamento }\end{array}$ & $\begin{array}{c}\text { Tempo de } \\
\text { tramitação } \\
\text { (aproximado) }\end{array}$ & Resultado \\
\hline $\begin{array}{c}\text { 0003837- } \\
\text { 70.2000.8.06.0115 }\end{array}$ & 22/07/2011 & $25 / 02 / 2014$ & 3 anos & $\begin{array}{c}\text { Improvido, } \\
\text { mantido o voto } \\
\text { do relator }\end{array}$ \\
\hline $\begin{array}{c}\text { 0087702- } \\
\text { 32.2006.8.06.0001 }\end{array}$ & $24 / 04 / 2012$ & $25 / 02 / 2014$ & 2 anos & $\begin{array}{c}\text { Providos, } \\
\text { prelecendo o } \\
\text { voto divergente }\end{array}$ \\
\hline $\begin{array}{c}\text { 0064477- } \\
\text { 12.2008.8.06.0000 }\end{array}$ & 28/01/2012 & $29 / 07 / 2014$ & 2 anos & $\begin{array}{l}\text { Improvidos, } \\
\text { mantendo a } \\
\text { decisão do } \\
\text { Relator }\end{array}$ \\
\hline $\begin{array}{c}\text { 0472495- } \\
\text { 38.2000.8.06.0000 }\end{array}$ & 22/03/1999 & $02 / 10 / 2014$ & 15 anos & $\begin{array}{c}\text { Improvidos, } \\
\text { acórdão } \\
\text { mantido. }\end{array}$ \\
\hline
\end{tabular}


Revista Eletrônica de Direito Processual - REDP.

Rio de Janeiro. Ano 13. Volume 20. Número 3. Setembro a Dezembro de 2019

Periódico Quadrimestral da Pós-Graduação Stricto Sensu em Direito Processual da UERJ

Patrono: José Carlos Barbosa Moreira (in mem.). ISSN 1982-7636. pp. 239-267

www.redp.uerj.br

\begin{tabular}{|c|c|c|c|c|}
\hline $\begin{array}{c}\text { 0499915- } \\
\text { 15.2000.8.06.0001 }\end{array}$ & $19 / 02 / 2013$ & $16 / 12 / 2014$ & 1 ano & $\begin{array}{c}\text { Improvido, } \\
\text { mantido o voto } \\
\text { do Relator }\end{array}$ \\
\hline $\begin{array}{c}\text { 0011776- } \\
\text { 53.2003.8.06.0000 }\end{array}$ & 29/03/1993 & $16 / 12 / 2014$ & 20 anos & $\begin{array}{c}\text { Provido, } \\
\text { prevalecendo o } \\
\text { voto divergente. }\end{array}$ \\
\hline $\begin{array}{c}\text { 0027761- } \\
\text { 49.2009.8.06.0001 }\end{array}$ & $06 / 05 / 2015$ & 29/09/2015 & 4 meses & $\begin{array}{l}\text { Improvido, } \\
\text { mantido o voto } \\
\text { do Relator }\end{array}$ \\
\hline $\begin{array}{c}\text { 0029126- } \\
\text { 75.2008.8.06.0001 }\end{array}$ & 26/02/2012 & $23 / 02 / 2016$ & 4 anos & $\begin{array}{l}\text { Improvidos, } \\
\text { mantido o voto } \\
\text { do Relator }\end{array}$ \\
\hline $\begin{array}{c}\text { 0000201- } \\
\text { 37.2010.8.06.0086 }\end{array}$ & $13 / 10 / 2014$ & $31 / 06 / 2016$ & 2 anos & $\begin{array}{c}\text { Não discute } \\
\text { questão de } \\
\text { divergência de } \\
\text { acórdão }\end{array}$ \\
\hline $\begin{array}{c}\text { 0001007- } \\
\text { 12.2000.8.06.0090 }\end{array}$ & 25/09/2013 & 26/06/2016 & 3 anos & $\begin{array}{c}\text { Providos, } \\
\text { acompanhando } \\
\text { o voto do } \\
\text { Relator. }\end{array}$ \\
\hline $\begin{array}{c}\text { 0456292- } \\
\text { 98.2000.8.06.0000 }\end{array}$ & $28 / 05 / 2001$ & $25 / 09 / 2017$ & 16 anos & $\begin{array}{l}\text { Provimento, } \\
\text { prevalecendo a } \\
\text { divergência }\end{array}$ \\
\hline $\begin{array}{c}\text { 0001838- } \\
\text { 84.2010.8.06.01.0001 }\end{array}$ & 26/06/2014 & $30 / 07 / 2018$ & 4 anos & $\begin{array}{c}\text { Improvido, } \\
\text { prevalecido o } \\
\text { voto divergente. }\end{array}$ \\
\hline $\begin{array}{c}\text { 0001838- } \\
\text { 84.2010.8.06.01.0001 }\end{array}$ & 26/06/2014 & 30/07/2018 & 4 anos & $\begin{array}{c}\text { Improvido, } \\
\text { prevalecido o } \\
\text { voto divergente. }\end{array}$ \\
\hline
\end{tabular}

Fonte: Elaboração própria, 2019. 